\title{
The Analysis of Mathematical Communication's Ability in Derivative Materials Observed from Introvert and Extrovert Personality Types
}

\author{
Salisa Rojiatur Rohmah ${ }^{1 *}$, Hanif Uli Rona ${ }^{1}$ \\ ${ }^{1}$ SMA Kartika Banyubiru, Semarang, Indonesia \\ *Corresponding author, email: lisa.amb21@gmail.com \\ DOI: $10.18326 /$ hipotenusa.v2i2.66-82
}

Article submitted : Agustus $28^{\text {th }}, 2020$

Article reviewed : October $27^{\text {th }}, 2020$

Article published : December $1^{\text {st }}, 2020$

\begin{abstract}
The purpose of this study is to determine mathematical communication skills that assessed from introvert and extrovert personality types, to determine the strengths and weaknesses of each personality type. This research is a qualitative descriptive study. The class subjects are students of SMA Kartika III-1 Banyubiru, grade XI MIPA 2 (Mathematics and Natural Science). The subjects of the research are 2 introvert and 2 extrovert personality types' students. The procedures of collecting data are written tests, interviews, questionnaires and documentation. The results of this study show that mathematical communication skills in terms of introvert personality type are able to meet 1 indicator. That is the ability to explain ideas, situations and mathematical relations in writing. In contrast, the extrovert personality type meets 2 indicators of mathematical communication skills. There is the ability to express daily events in language or mathematical symbols and the ability to read mathematical symbols. The strengths of introvert personality type are able to explain ideas verbally and in writing. Then the weaknesses are difficult to understand the problem of mathematical images and symbols. In contrast to the introvert, extrovert personality's strengths are able to understand mathematical symbols, and then its weaknesses are hard to understand mathematics questions.
\end{abstract}

Key words: Mathematical communication, introvert, extrovert 


\section{Jurnal Hipotenusa, 2 (2), December 2020}

Salisa Rojiatur Rohmah and Hanif Uli Rona

\section{INTRODUCTION}

Mathematics is a branch of science that plays an important role in the development of other sciences, so mathematics is often referred to the mother of science (Ranti, 2015). In other words, mathematics does not depend on other sciences. However, mathematics becomes the foundation of other sciences.

The development of Science and Technology (IPTEK) rapidly, especially in the field of informational technology, is one of the mathematics' roles. To master and create future technology requires mathematics' mastery firmly since early childhood. So, it is important to equip ourselves to face any challenges in this growth developing life. The provisions that must be prepared have the ability to think critically, logically, systematically, work together, compete, reliable and hardly give up (L. D. Rahayu \& Kusuma, 2019).

The ability to think critically, systematically logically, cooperate, compete, be reliable and hardly give up can be trained through mathematics learning. Mathematics is a lesson that reflects these abilities because mathematics is a basic science that plays an important role in the development of science and technology in recent times. If math skills are low, then it cannot adapt to recent times (L. D. Rahayu \& Kusuma, 2019). This is in line with the objectives of learning mathematics, namely educating children to think logically, critically, systematically, be objective, honest and discipline's characteristics in solving problems of mathematics, other fields, and in everyday life (Maqfiroh, 2016 ). By using this ability, it is concerned that students will be able to face recent developments and changes.

Furthermore, the competencies that are developed in mathematics lessons include problem-solving, communications, reasoning, connections, and representations (KarimiFardinpour \& Gooya, 2017; NCTM, 1998). Meanwhile, De Lang (2009) states that the competencies and abilities that should be mastered by students during the mathematics learning process in class at least consist of eight competencies, namely: (1) thinking and reasoning mathematically, (2) arguing mathematically, (3) communicating mathematically, (4) modelling, (5) preparation and problem solving, (6) representation, (7) symbols, and (8) tools and technology. The previous description states that mathematical communication skills are an important aspect to be developed in the mathematics learning process. 
Mathematical communication skills are the way of sharing ideas that are focused more on speaking, writing, drawing and explaining mathematical concepts (Van De Walle et al., 2008: 4). This ability gives an opportunity for students to explore ideas or thought, then communicate to others orally or in writing through communicating students in using mathematical language. The use of appropriate language in communication is written in QS. Ibrahim verse 4 which says:

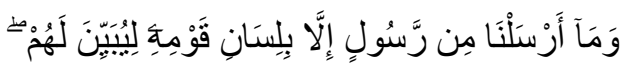

Meaning: "We have not sent a Messenger except in the language of his people to clarify 'the message' for them..." (QS. Ibrahim verse 4).

The above verse explains that the Messenger chooses proper languages in his communication so that it would be more understandable to people. By communication, it is possible to express the ideas clearly with understandable language. This also exists in mathematics learning which is called mathematical communication skills. This ability trains students to express ideas either in writing or orally in their own languages which is easily understood by many people. Learning communication in mathematics helps students to develop interactions and expresses ideas in the classroom because they are studying in an active learning process (Kumalaretna, 2017; Rosnawati \& Pendahuluan, 2013).

Students' mathematical communication skills ability cannot be separated from the teachers' role as an educator. Teachers have full responsibility in the class during the learning process. Setting up and making a lesson plan in order to engage students to express their thought can help students improve their mathematical communication skills. So that teachers need to create an attractive learning environment and help students understand mathematical concepts in developing mathematical communication skills (Mariani, 2017; Nurina \& Retnawati, 2015; Umami, 2015; Yusuf et al., 2017).

Baroody (1993) states that there are two important reasons for acknowledging mathematical communication skills. First, mathematics as a language. It means that mathematics is not as thinking's tools, finding formulas, solving problems, or simply concluding, but it also has unlimited values in expressing various ideas clearly, accurately and precisely. Second, mathematics learning as a social activity, which means as a social activity in learning mathematics, as well as a medium for interaction 
among students, and communication's tools between teachers and students (Umar, 2012). This becomes important to develop students' potential in expressing ideas or thought and improve understanding of mathematical concepts.

Based on the results of observations and interviews from mathematics' teachers, it is found that the mathematical communication skills of Grade XI's students are still low. They are difficult to formulate mathematical models from narrated story questions. Students tend to write answers shortly and incoherently because they cannot understand the questions clearly. Then there are also some students who do not make conclusions when solving problems. Moreover, the lack of comprehension of mathematical concepts happens when some students only memorize formulas without knowing their application. This causes students facing difficulty while solving problems. On the other hand, they have a problem with mentioning mathematical symbols or notations. It shows when students are confused to determine the sign of more than ">" or less than $"<"$ in solving narrated story questions. Meanwhile, the interaction between students and teachers in the learning process is still ineffective, and students seem hesitant when the teacher asks them to answer the questions.

In teaching and learning activities, it is often found that some students easily convey their thoughts' results and also students who are incapable of expressing their ideas. This happens because of student personality's differentiation. Different personality will affect how a person receives, processes, and delivers information to others. The way to communicate and respond to the problems among individuals is different because of a mindset influence based on their personality (Melya, 2018: 3)..

Two personality types, extrovert and introvert, are the most highlighted personality in the learning process. Extrovert students tend to talk more, active and think objectively while introvert students tend to be silent, passive and think subjectively (Hasanah \& and Sutrima, 2013; Virlia, 2018). The characteristics of the extrovert type are gathered in group, fast response and requires feedback from the teacher during the learning process. Then, the characteristics of introverts are selfisolated (prefer to study alone), careful in making decisions, calm and diligent (ARINI, 2016; Arsyad, Asdar, 2018; Pangestu \& Hasti Yunianta, 2019). 
According to a psychologist, Carl Gustav Jung states that introvert and extrovert personality types are part of personality types' group. Introvert students tend to face difficulties in verbal communication (Schat, 2012; Schmidt, 2016). This happens because they prefer to be alone so that their ability to build social relationships is low, and they are less interested in activities that involve groups (Nurjannah, 2019).

Meanwhile, one of the characteristics of extrovert personality types is easy to keep in touch with others. Then this type has better verbal communication. They easily express ideas or thought verbally because they are open to others (Amichai-Hamburger et al., 2002; Farrell, 2017; Schat, 2012). The ability to make friends and create social interactions seen in extrovert personality eases them develop mathematical communication skills than introvert students (Yukentin et al., 2018). Because in the learning process extroverts prefer to study in the group while introverts prefer to study alone (Schat, 2012). So it is easy for extrovert students to convey their ideas or thought to other students or teacher. This is based on the statement which underlines that mathematical communication skills happen when students learn in groups (Asnawati, 2017; Mikrayanti, 2012; Syasri et al., 2018).

Mathematical communication skills do not only occur in transferring messages of a particular subject among students or teachers and students, but also happens when students have abilities to use vocabularies, notations, and mathematical structures in reasoning, connection and problem-solving (Syasri et al., 2018). In this case, introvert students have better reasoning skills in solving problems than extrovert students. This is in line with the research's results done by Rahayu \& Fauziah (2017), which states that introvert students meet four indicators while extrovert students meet three indicators.

Based on the above description, it shows that there is a relationship between each personality type and mathematical communication skills. Therefore, the researchers are more interested in students' mathematical communication skills which focused on those personalities. 


\section{Jurnal Hipotenusa, 2 (2), December 2020}

Salisa Rojiatur Rohmah and Hanif Uli Rona

\section{METHOD}

This research uses a qualitative approach, and its type is descriptive qualitative research. The research is conducted in SMA Kartika III-1 Banyubiru which is located at Jalan Raya Muncul No. 4, Ngorok, Kebondowo, Banyubiru, Semarang, Central Java 50664.

Data collection procedures are systematic and standard procedures to obtain the required data (Arikunto, 2010: 265). Data collection procedures in this research included the results of questionnaires, tests, interviews and documentation. Questionnaires are used to classify students' personality types, tests to determine mathematical communication skills, interviews are used to obtain more information related to mathematical communication skills, and documentation is used to get data of student names, work results, and other data needed for the research.

Furthermore, the researchers select the research's subject; there are 2 introvert students and 2 extrovert students. The determination of the research subject is carried out by using purposive technique or selection with certain considerations. This selection is taken after students filling out a questionnaire of students' classification and answering mathematical communication skills' tests. The results of the questionnaire and test are used to select 2 students from each personality type who has the highest mathematical communication ability. Furthermore, the selection of the subject considers the willingness of students and the ability to express their ideas or argument verbally during the interview after taking the mathematical communication skills test.

In qualitative research, data validity factor needs to be considered. Data validity is used to check the validity of the obtained data. Then, this research uses triangulation techniques. The triangulation of data collection is aimed to check the results of mathematical communication skills' tests and interviews with research subjects.

\section{RESULTS AND DISCUSSION}

First, researchers will classify personality type. Second, they conduct tests of mathematical communication skills and interviews. Then, the classification of an introvert and extrovert students' personality types is based on Eysenck's Personality Inventory (EPI) questionnaire, which has 24 questions. The result shows that $42 \%$ most respondents are categorized as introvert, and 58\% are extrovert. 
Jurnal Hipotenusa, 2 (2), December 2020

Salisa Rojiatur Rohmah and Hanif Uli Rona

Table 1. Personality Types' Classification

\begin{tabular}{|c|c|c|c|c|c|}
\hline No. & $\begin{array}{l}\text { Student's } \\
\text { Code }\end{array}$ & Personality Type & No. & $\begin{array}{l}\text { Student's } \\
\text { Code }\end{array}$ & Personality Type \\
\hline 1 & $\mathrm{~S}-2$ & \multirow{19}{*}{ Introvert } & 15 & S-1 & \multirow{19}{*}{ Extrovert } \\
\hline 2 & S-4 & & 16 & $S-3$ & \\
\hline 3 & S-6 & & 17 & S-5 & \\
\hline 4 & S-7 & & 18 & S-8 & \\
\hline 5 & S-11 & & 19 & $S-9$ & \\
\hline 6 & $S-15$ & & 20 & $S-10$ & \\
\hline 7 & S-17 & & 21 & S-12 & \\
\hline 8 & $S-23$ & & 22 & $S-13$ & \\
\hline 9 & S-24 & & 23 & S14 & \\
\hline 10 & $S-25$ & & 24 & $S-16$ & \\
\hline 11 & S-26 & & 25 & S-18 & \\
\hline 12 & $S-30$ & & 26 & S-19 & \\
\hline 13 & S-31 & & 27 & S-20 & \\
\hline \multirow[t]{6}{*}{14} & $S-33$ & & 28 & $S-21$ & \\
\hline & & & 29 & S-22 & \\
\hline & & & 30 & S-27 & \\
\hline & & & 31 & S-28 & \\
\hline & & & 32 & S-29 & \\
\hline & & & 33 & S-32 & \\
\hline
\end{tabular}

Mathematical communication skills' test is conducted by 31 students. There are 2 absent students. This test is taken individually. The test is used by researchers to determine mathematical communication skills. It will be next checked with research subjects' results. The results of the mathematical communication skills test show that mathematical communication skills between introverts and extroverts are close to each other. The average result of introvert students is 27 , and extrovert students get 2 points higher 29. Another fact shows that students could not answer the question correctly.

After finding the classification of personality types and the mathematical communication skills tests' results, the researchers determine the research subjects. The selected research subjects are 2 introvert students and 2 extrovert students. This 
selection is based on the result of their mathematical communication skills' test, classification of personality types and the willingness of the subjects to participate in the data collection process entirely. The results of determining the subject are as follows.

Table 2. Classification of Research Subject's Result

\begin{tabular}{|c|c|c|c|}
\hline No. & $\begin{array}{l}\text { Student's } \\
\text { Code }\end{array}$ & Personality Type & Subject's Code \\
\hline 1 & S-17 & Introvert & $\mathrm{I}-1$ \\
\hline 2 & S-25 & Introvert & $\mathrm{I}-2$ \\
\hline 3 & $\mathrm{~S}-23$ & Extrovert & E-1 \\
\hline 4 & S-31 & Extrovert & E-2 \\
\hline
\end{tabular}

The analysis of mathematical communication skills of every subject is based on 3 indicators of mathematical communication skills. Those indicators are the ability to write, draw, and express mathematical ideas. The definition of writing ability here is the students' ability to explain mathematical ideas, situations or problems in writing. It can be seen from the student's ability to write given and asked information, process and conclusions.

The meaning of drawing ability's indicator is that students can reflect images into mathematical ideas. This can be seen from students' ability to write known information from answering pictures and be able to solve problems so that they can give conclusions.

The indicator of the ability to express mathematical ideas is that students can describe daily events in language or mathematical symbols. It can be found from students' ability to use symbols in answering questions.

The research subjects are categorized as capable if they are able to write indicators completely and correctly. Then, one is less capable if the subjects could not meet the indicators' criteria fully or incompletely or make some mistakes. Last, one is incapable if one could not meet the indicator's criteria.

\section{Mathematical communication ability which is seen from introvert personality}

In this research, the interview subjects for mathematical communication skills with introvert personality types are I-1 and I-2. The analysis result that has been carried 
out from mathematical communication skills' test result and the results which come from subject I-1 and I-2's interview have not met 3 indicators of mathematical communication skills. The results of the respondent's work can be seen in Figure 1.
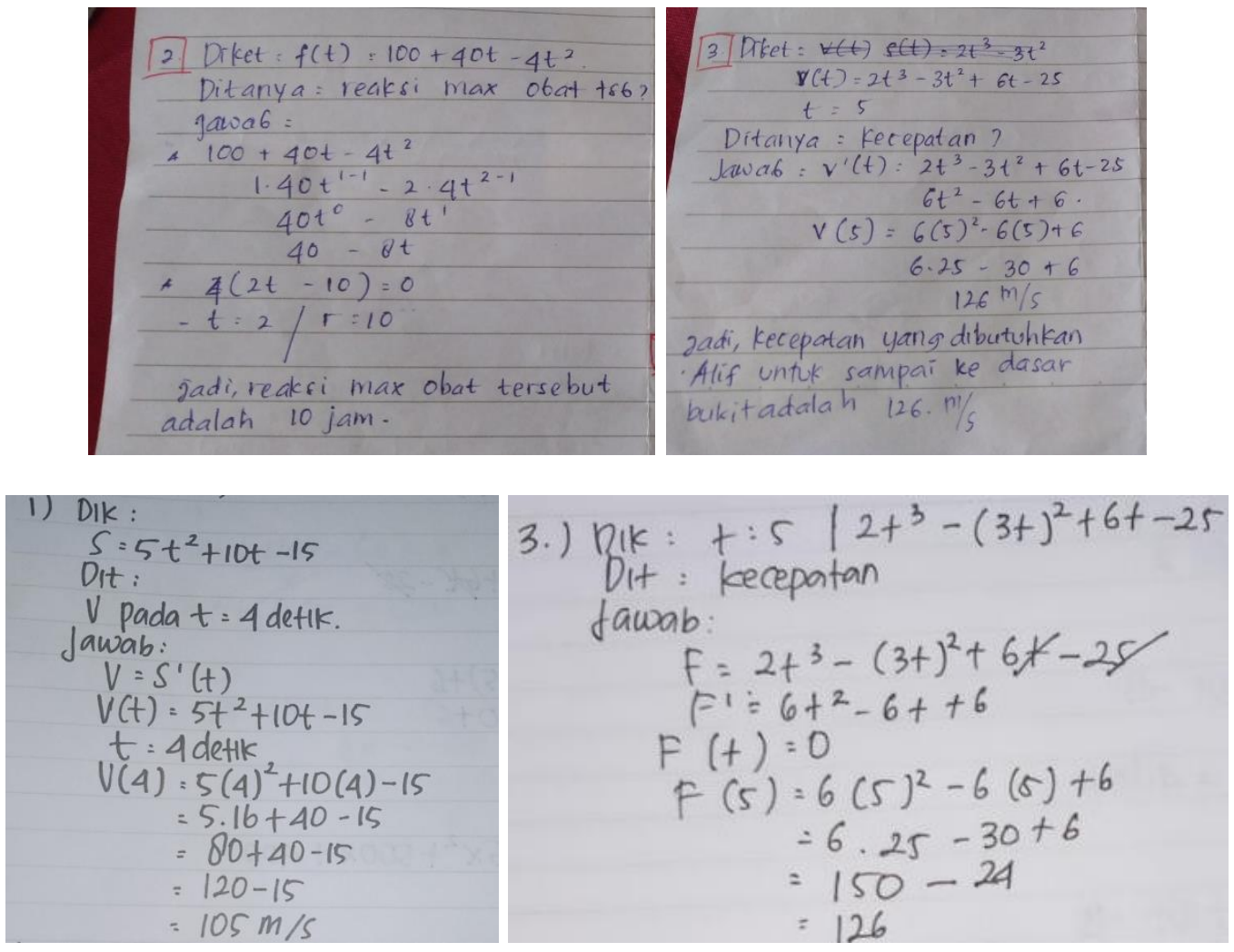

Figure 1. Introvert Students' Work

In writing indicators, subject I-1's mathematical communication skills are inaccurate in answering the question, so that the results are inaccurate. Moreover, the answer from subject I-2 is incoherent; he missed the step. Therefore it can be concluded that the introverted personality type has not been able to meet the writing indicators yet; explaining ideas, situations and mathematical problems in writing.

In drawing indicators, the mathematical communication skills of subject I-1 and I-2 are unable to state known information accurately. Then the subject I-2 could not write a conclusion. Based on this, it can be concluded that the introverted personality type has not been able to meet the drawing indicators yet, namely reflecting images into mathematical ideas.

However, the indicators of mathematical expressions, mathematical communication skills of subject I-1's do not show or use symbols in the asked 
information of the question no.1. Subjects I-1 cannot distinguish between the symbols $s(t)$ and $v(t)$. Subject I-2 also does not use symbols in the known and asked information. Additionally, the subject uses the wrong symbol to denote speed. Based on this, it can be concluded that the introvert personality type has not been able to meet the mathematical expressions' indicators, namely expressing daily events with language or mathematical symbols.

\section{Mathematical communication ability which is seen from introvert personality}

The interview subjects of mathematical communication skills by extrovert personality types are E-1 and E-2. The results of the analysis that have been carried out from the results of mathematical communication skills test' results and the results of interview E-1 and E-2 subjects have not been able to draw indicators and mathematical expressions and less capable in writing indicators. The extrovert students' work results can be seen in Figure 2.
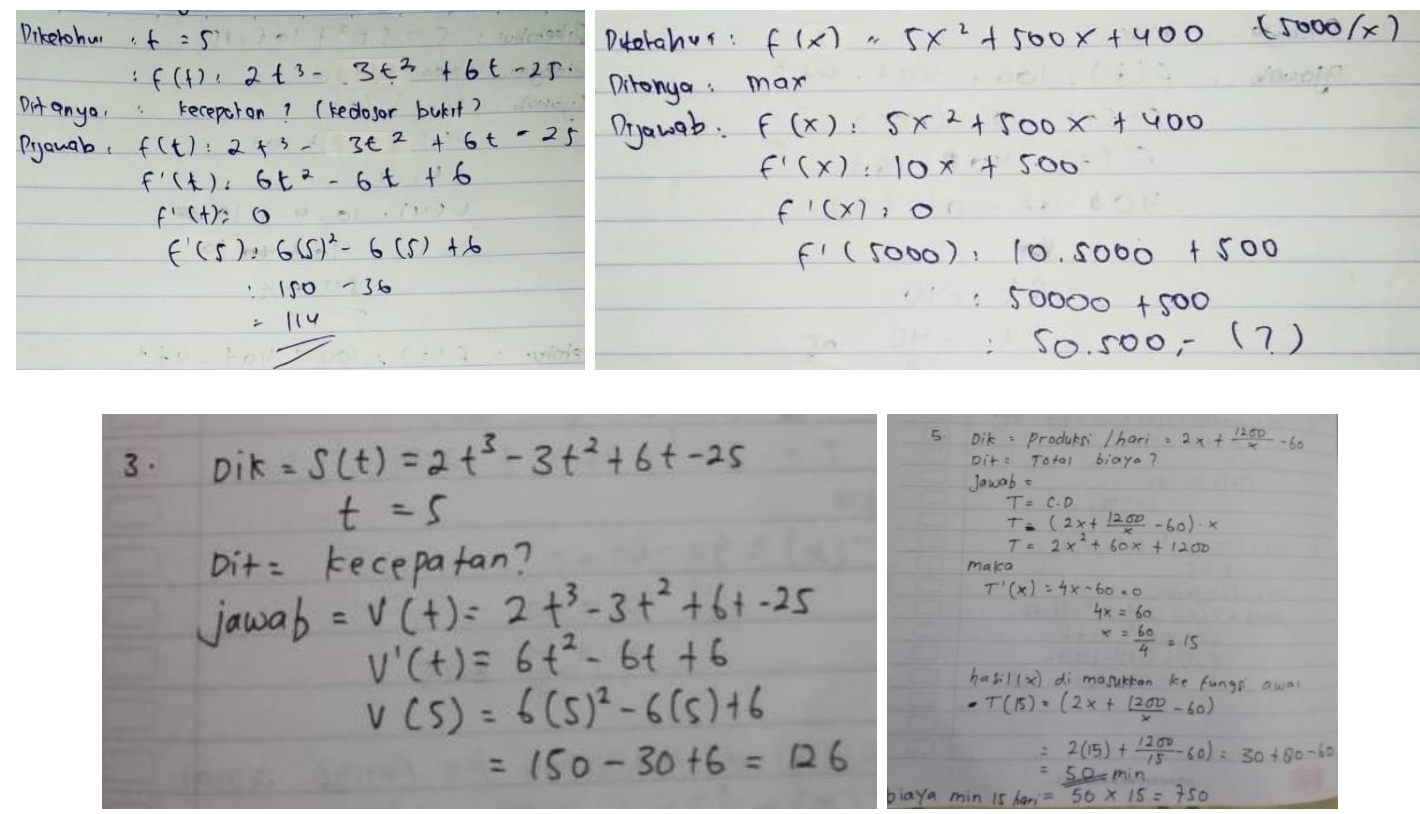

Figure 2. Extrovert Students' Work Result

Thus, the writing indicators, E-1 subject on the communication skills shows that he cannot understand the question well so that the answer is incorrect. Subject E-2 is unable to write a conclusion at the end of the process. Based on this, it can be concluded that the extrovert personality type is not able to meet the writing indicators completely, namely explaining ideas, situations and problems in writing. 
The indicators of drawing the communication skills of the E-1 subject, the calculations are incorrect and without giving conclusions. E-2 subject does not write conclusions. Based on this, it can be concluded that the extrovert personality type has not been able to meet the drawing indicators, namely reflecting images into mathematical ideas.

Moreover, the indicators of a mathematical expression, mathematical communication skills of E-1 subject are not presenting symbols toward the asked information, and the used symbols are incorrect, which found in question number 3. While E-2 subject, the used symbols in no 3 are incorrect. He does not include symbols in known information. Based on this, it can be concluded that the extrovert personality type is less capable yet toward mathematical expressions' indicators, namely expressing daily events by language (verbally).

\section{Strength and Weakness of Introvert}

The introvert personality type has strength in writing indicators. He can explain the obtained information and its completion steps. On the drawing indicator, introverts are able to explain verbally. The weakness of introverts in writing indicators is that they seem careless in answering the questions. Then, in the drawing's indicators, they face difficulties in explaining orally. Introverts also cannot distinguish mathematical symbols for problem-solving yet.

Based on table 3, it can be seen that the introvert personality type has strength in writing indicators. There is the ability to explain the obtained information and completion steps. Then the indicators of drawing, introverts can explain verbally. Meanwhile, the weakness of introverts in writing indicators is that they do not work thoroughly. On the indicators of drawing, they find difficulties in explaining orally. Introverts also cannot distinguish mathematical symbols for problem-solving. So, the strength and weakness of extrovert personality type can be observed in table 4 . 
Table 3. Strength and Weakness of Introvert Personality Type

\begin{tabular}{lll}
\hline \multicolumn{1}{c}{ Indicator } & \multicolumn{1}{c}{ Strength } & \multicolumn{1}{c}{ Weakness } \\
\hline $\begin{array}{l}\text { Writing, } \\
\begin{array}{l}\text { Explaining an idea, } \\
\text { situation or problem in } \\
\text { writing }\end{array}\end{array}$ & $\begin{array}{l}\text { It was able to explain ideas to } \\
\text { solve problems orally. }\end{array}$ & $\begin{array}{l}\text { Some steps are } \\
\text { missed or less } \\
\text { accurate. }\end{array}$ \\
$\begin{array}{l}\text { Drawing, } \\
\begin{array}{l}\text { It is reflecting images } \\
\text { into mathematical ideas. }\end{array}\end{array}$ & $\begin{array}{l}\text { Information and completion steps } \\
\text { on the answer sheet coherently } \\
\text { and correctly. }\end{array}$ & $\begin{array}{l}\text { We are facing } \\
\text { difficulty to explain } \\
\text { known information } \\
\text { orally. }\end{array}$ \\
$\begin{array}{l}\text { Mathematical } \\
\text { expressions }\end{array}$ & $\begin{array}{l}\text { Expressing daily events } \\
\text { in language or } \\
\text { mathematical symbols }\end{array}$ & $\begin{array}{l}\text { Not being able to } \\
\text { differentiate } s(\mathrm{t}), v(\mathrm{t}), \\
\text { dan } f(\mathrm{t}) .\end{array}$ \\
\hline
\end{tabular}

Table 4. Strength and Weakness of Extrovert Personality Type

\begin{tabular}{lll}
\hline \multicolumn{1}{c}{ Indicator } & \multicolumn{1}{c}{ Strength } & \multicolumn{1}{c}{ Weakness } \\
\hline $\begin{array}{l}\text { Writing, } \\
\begin{array}{l}\text { Explaining an idea, } \\
\text { situation or problem in } \\
\text { writing }\end{array}\end{array}$ & $\begin{array}{l}\text { It was able to explain the } \\
\text { information from the } \\
\text { questions verbally. }\end{array}$ & $\begin{array}{l}\text { Being able or not being able } \\
\text { to understand the questions } \\
\text { well. }\end{array}$ \\
$\begin{array}{l}\text { Drawing } \\
\begin{array}{l}\text { Reflecting images into } \\
\text { mathematical ideas }\end{array}\end{array}$ & $\begin{array}{l}\text { information from pictures } \\
\text { orally }\end{array}$ & $\begin{array}{l}\text { The results are incorrect. } \\
\text { Thect is not thorough. }\end{array}$ \\
$\begin{array}{l}\text { Mathematical } \\
\text { expressions }\end{array}$ & $\begin{array}{l}\text { It was able to read math } \\
\text { symbols precisely. } \\
\text { in language or } \\
\text { mathematical symbols }\end{array}$ & \\
\hline
\end{tabular}


The strengths of the extrovert personality type can be seen from the results of writing indicators, namely explaining information verbally. In drawing indicators, they can explain drawing information verbally, and read the used symbols. Meanwhile, the weakness of the extrovert personality type is the ability to understand the problem well but not thoroughly yet. Table 5 describes the comparison of mathematical communication skills between introvert and extrovert personality types.

Table 5. Comparison of Mathematical Communication Abilities of Introvert and Extrovert Personality Types.

\begin{tabular}{lll}
\hline \multicolumn{1}{c}{ Indicator } & \multicolumn{1}{c}{ Introvert } & \multicolumn{1}{c}{ Extrovert } \\
\hline $\begin{array}{l}\text { Writing, which is } \\
\text { explaining a } \\
\text { mathematical idea, } \\
\text { situation or problem } \\
\text { in writing. }\end{array}$ & $\begin{array}{l}\text { Being able to write asked and } \\
\text { known information, but in the } \\
\text { solving problem is still } \\
\text { incorrect because the subject } \\
\text { does not answer thoroughly. }\end{array}$ & $\begin{array}{l}\text { Being able to write asked } \\
\text { and known information but } \\
\text { the process is incorrect. } \\
\text { But the subject can explain } \\
\text { verbally. }\end{array}$ \\
$\begin{array}{l}\text { Drawing, namely } \\
\text { reflecting images } \\
\text { into mathematical } \\
\text { ideas. }\end{array}$ & $\begin{array}{l}\text { Being able to write asked and } \\
\text { known information and } \\
\text { complete it coherently and } \\
\text { accurately. However, during } \\
\text { the interview, the subject is } \\
\text { difficult to explain the known } \\
\text { information correctly. }\end{array}$ & $\begin{array}{l}\text { Being able to write asked, } \\
\text { known, answered } \\
\text { information. } \\
\text { Being able to finish } \\
\text { (question) but the result is } \\
\text { not incorrect on E-1 subject } \\
\text { and E-2 subject can finish } \\
\text { correctly. }\end{array}$ \\
$\begin{array}{l}\text { Mathematical } \\
\text { expressions, namely } \\
\text { expressing daily } \\
\text { events in language or } \\
\text { mathematical } \\
\text { symbols }\end{array}$ & $\begin{array}{l}\text { Being able to use and explain } \\
\text { mathematical symbols even } \\
\text { though inaccurate. }\end{array}$ & $\begin{array}{l}\text { Being able to write } \\
\text { mathematical symbols and } \\
\text { can explain orally. Not } \\
\text { using symbols in known } \\
\text { and asked information. }\end{array}$ \\
\hline
\end{tabular}




\section{Jurnal Hipotenusa, 2 (2), December 2020}

Salisa Rojiatur Rohmah and Hanif Uli Rona

\section{CONCLUSION}

Students' mathematical communication skills which are observed from introverted personality type only meet one indicator. They are able to explain mathematical ideas, situations or relations in writing. Meanwhile, extroverted students' mathematical communication skills meet two indicators, namely (1) being able to express daily events in the language (verbally) or mathematical symbols, (2) being able to read mathematical used symbols. Then, the strength of the introverted personality type is that one can explain ideas to solve problems orally and in writing. So that the obtained results are correct. Meanwhile, the weakness of the introvert personality type is less capable of reading known information from pictures and mathematical symbols completely. However, the extrovert personality type's strength is that one can read and use mathematical symbols and also explain the obtained information obtained orally. While the extroverts' weakness is answering the questions briefly but less-understanding the questions completely so that the used ideas to solve the problem are inaccurate.

\section{REFERENCES}

Amichai-Hamburger, Y., Wainapel, G., \& Fox, S. (2002). "On the internet no one knows I'm an introvert": Extroversion, neuroticism, and internet interaction. Cyberpsychology and Behavior. https://doi.org/10.1089/109493102753770507

ARINI, Z. (2016). PROFIL KEMAMPUAN PENALARAN SISWA SMP DALAM MENYELESAIKAN MASALAH MATEMATIKA DITINJAU DARI TIPE KEPRIBADIAN EXTROVERT DAN INTROVERT. MATHEdunesa.

Arsyad, Asdar, M. (2018). Pengaruh Penerapan Model Pembelajaran Kooperatif dengan Strategi Think Talk Write terhadap Kemampuan Penalaran , dan Komunikasi matematis , serta Motivasi Belajar Siswa dalam Pembelajaran Matematika di SMPN 1 Sinjai Utara. Issues in Mathematics Education, 2(1), 1-16.

Asnawati, S. (2017). Peningkatan Kemampuan Komunikasi Matematis Siswa Smp Dengan Pembelajaran Kooperatif Tipe Teams-Gamestournaments. Euclid, 3(2), 561-567. https://doi.org/10.33603/e.v3i2.332

De Lang, J. (2009). PISA 2009 Assessment Framework Key Competencies in Reading , Mathematics and Science. 
Farrell, M. (2017). Leadership Reflections: Extrovert and Introvert Leaders. Journal of Library Administration. https://doi.org/10.1080/01930826.2017.1300455

Hasanah, N. M., \& dan Sutrima. (2013). Analisis Proses Berpikir Siswa Dalam Memecahkan masalah Matematika Ditinjau dari Tipe Kepribadian EstrovertIntrovert dan Gender. Jurnal Pasca UNS.

KarimiFardinpour, Y., \& Gooya, Z. (2017). Comparing Three Methods of Geometrical Approach in Visualizing Differential Equations. International Journal of Research in Undergraduate Mathematics Education, Nctm 2000.

https://doi.org/10.1007/s40753-017-0061-6

Kumalaretna, W. N. D. (2017). Kemampuan Komunikasi Matematis Ditinjau dari Karakter Kolaborasi dalam Pembelajaran Project Based Learning (Pjbl). Unnes Journal of Mathematics Education Research, 6(2), 195-205.

Maqfiroh, F. (2016). MENINGKATKAN KOMUNIKASI MATEMATIKA MELALUI MODEL PEMBELAJARAN PBL (PROBLEM BASED LEARNING) BERBASIS CIRC (COOPERATIVE INTEGRATED READING AND COMPOSITION.

Universitas Muhammadiyah Surakarta.

Mariani, M. (2017). Penerapan Model Pembelajaran Make a Match Untuk Meningkatkan Hasil Belajar Matematika Tentang Pembagian Pada Siswa Kelas Ii Sd Muhammadiyah 4 Batu. JINoP (Jurnal Inovasi Pembelajaran), 3(2), 599-608. https://doi.org/10.22219/jinop.v3i2.5306

Mikrayanti. (2012). MENINGKATKAN KEMAMPUAN PENALARAN DAN KOMUNIKASI MATEMATIS SISWA SEKOLAH MENENGAH ATAS MELALUI PEMBELAJARAN BERBASIS MASALAH :Studi Kuasi Eksperimen pada Siswa SMA di Kabupaten Bima. Universitas Pendidikan Indonesia.

NCTM. (1998). Executive Summary Principles and Standards for School Mathematics Overview. Journal of Equine Veterinary Science, 18(11), 719. https://doi.org/10.1016/s0737-0806(98)80482-6

Nurina, D. L., \& Retnawati, H. (2015). Keefektifan Pembelajaran Menggunakan Pendekatan Problem Posing dan Pendekatan Open-Ended Ditinjau Dari HOTS. PYTHAGORAS: Jurnal Pendidikan Matematika, 10(2), 129. 
Jurnal Hipotenusa, 2 (2), December 2020

Salisa Rojiatur Rohmah and Hanif Uli Rona

https://doi.org/10.21831/pg.v10i2.9128

Nurjannah. (2019). Analisis Kemampuan Komunikasi Matematis Siswa Tipe

Kepribadian Introvert dalam Meneyelsaikan Soal Program Linier di SMAN 1

Muaro Jambi (Vol. 22). Universitas Jambi.

Pangestu, N. S., \& Hasti Yunianta, T. N. (2019). Proses Berpikir Kreatif Matematis

Siswa Extrovert dan Introvert SMP Kelas VIII Berdasarkan Tahapan Wallas.

Mosharafa: Jurnal Pendidikan Matematika.

https://doi.org/10.31980/mosharafa.v8i2.472

Rahayu, L. D., \& Kusuma, A. B. (2019). Peran Pendidikan Matematika di Era Globalisasi. Prosiding Sendika, 5(1), 534-541.

Rahayu, Y. M., \& Fauziah, N. M. (2017). Dari Kepribadian Introvert dan Extrovert pada Materi Kalor. E-Journal Unesa, 05(2), 138-146.

Ranti, M. G. (2015). SISWA MENGGUNAKAN STRATEGI WRITING TO LEARN PADA. 1(2), 94-100.

Rosnawati, R., \& Pendahuluan, A. (2013). Asesmen Formatif Informal dalam Pembelajaran Matematika. Penguatan Peran Matematika Dan Pendidikan Matematika Untuk Indonesia Yang Lebih Baik, ISBN : 978-979-16353-9-4, 473478.

Schat, S. (2012). Quiet: The Power of Introvert in a World That Can't Stop Talking. Brock Education Journal. https://doi.org/10.26522/brocked.v22i1.310

Schmidt, S. J. (2016). Personality Diversity: Extrovert and Introvert Temperaments. In Journal of Food Science Education. https://doi.org/10.1111/1541-4329.12091

Syasri, S. I. R., Hasanuddin, H., \& Noviarni, N. (2018). Peningkatan Kemampuan Komunikasi Matematis: Pengembangan Lembar Kerja Siswa Berbasis Model Pembelajaran Kooperatif Tipe Think Talk Write untuk Siswa Sekolah Menengah Pertama. JURING (Journal for Research in Mathematics Learning), 1(1), 43. https://doi.org/10.24014/juring.v1i1.4770

Umami, R. (2015). PERANAN KOMUNIKASI MATEMATIKA GURU DALAM MENGEMBANGKAN KEMAMPUAN KOMUNIKASI DAN PEMAHAMAN 
MATEMATIKA SISWA. WAHANA, 64(1), 17-24.

Umar, W. (2012). Membangun Kemampuan Komunikasi Matematis Dalam Pembelajaran Matematika. Infinity Journal, 1(1), 1. https://doi.org/10.22460/infinity.v1i1.2

Virlia, S. (2018). Hubungan Tipe Kepribadian Ekstrovert-Introvert dengan Penerimaan Sosial Pada Siswa. Konselor.

Yukentin, Y., Munawaroh, M., \& Winarso, W. (2018). Analisis Hasil Belajar Matematika Siswa Ditinjau Dari Perbedaan Kepribadian Ekstrovert Dan Introvert. JIPMat, 3(2), 163-168. https://doi.org/10.26877/jipmat.v3i2.2700

Yusuf, Y., Titat, N., \& Yuliawati, T. (2017). Analisis Hambatan Belajar (Learning Obstacle) Siswa SMP Pada Materi Statistika. AKSIOMA : Jurnal Matematika Dan Pendidikan Matematika, 8(1), 76-86.

http://journal.upgris.ac.id/index.php/aksioma/article/view/1509/1284 